\title{
НОРМАТИВНО-ПРАВОВЕ ЗАБЕЗПЕЧЕННЯ УЧАСТІ ГРОМАДСЬКОСТІ В ПІДВИЩЕННІ ЕФЕКТИВНОСТІ ФУНКЦІОНУВАННЯ ОРГАНІВ ВИКОНАВЧОЇ ВЛАДИ: АКТИ ДОПОМІЖНОГО ХАРАКТЕРУ Й ПЕРСПЕКТИВНЕ ЗАКОНОДАВСТВО
}

Юpax B. M.

Стаття присвячена огляду актів допоміжного характеру, які є складовими елементами системи нормативно-правового забезпечення участі громадськості в підвищенні ефективності функціонування органів виконавчоі влади. Визначено, що проблемою правового забезпечення досліджуваної участі є відсутність в країні правової обізнаності навіть серед посадових осіб. Зокрема, непоодинокими є випадки, коли посадові особи органів виконавчоі влади керуються роз'ясненнями, внутрішніми інструкціями (навіть усупереч нормам закону) в одних випадках, а в інших - ігнорують як норми закону, так і роз'яснення до них. Така ситуація обумовлена в тому числі й тим, що процес участі громадськості в управлінні державними справами не прописаний чітко в єдиному законодавчому акті, яким усувалися 6 численні суперечності й необхідність у додаткових роз'ясненнях. Зроблено висновок, що основною метою правового регулювання участі громадськості в управлінні державними справами має бути не впорядкування громадянського суспільства та його інституцій, а правове забезпечення належної реалізації права громадян на означену участь, створення системи доступної, зрозумілої й чіткої ієрархї нормативно-правових актів, в яких має бути послідовно й доступно окреслено можливості громадян у вказаній сфері, визначено суб'єктів, які здійснюють че забезпечення, установлено форми участі громадськості в управлінні державними справами, визначено права й обов'язки як державних суб'єктів, так і громадськості (окремих громадян чи громадських організацій, інших інститутів громадянського суспільства), встановлено відповідальність. У цьому процесі вагомий вплив на формування означеної ієрархії здійснюють акти допоміжного характеру, які також потребують певного упорядкування та, щонайперше, відповідності законам, тобто вони мають його роз'яснювати, тлумачити, а не доповнювати чи заповнювати прогалини. Аналіз проєктованого законодавства допомагає відстежити тенденції в українському суспільстві, але поки що не дає можливості робити висновки про майбутні засади участі громадськості в управлінні державними справами через постійні зміни й непослідовність у процесі роботи над ним.

Ключові слова: участь громадськості, нормативно-правове забезпечення, роз'яснення, проєкт, рішення суду, управління державними справами.

Статья посвящена обзору актов вспомогательного характера, которые являются составным элементом системы нормативно-правового обеспечения участия общественности в повышении эффективности функционирования органов исполнительной власти. Определено, что проблемой правового обеспечения исследуемого участия

Юрах B. M., 2019 является отсутствие в стране правовой осведомленности даже среди должностных лиц. В частности, нередки случаи, когда должностные лица органов исполнительной власти руководствуются разъяснениями, внутренними инструкциями (даже вопреки нормам закона) в одних случаях, а в других - игнорируют как нормы закона, так и разъяснения к ним. Такая ситуация обусловлена в том числе и тем, что процесс участия общественности в управлении государственными делами не прописан четко в едином законодательном акте, каким бы устранялись многочисленные противоречия и необходимость в дополнительных разъяснениях. Сделан вывод, что основной целью правового регулирования участия общественности в управлении государственными делами должно быть не упорядочение гражданского общества и его институтов, а правовое обеспечение надлежащей реализации права граждан на указанное участие, создание системы доступной, понятной и четкой иерархии нормативно-правовых актов, в которых должны быть последовательно и доступно определены возможности граждан в указанной сфере, субъекты, осуществляющие означенное обеспечение, установлены формы участия общественности в управлении государственными делами, определены права и обязанности как государственных субъектов, так и общественности (отдельных граждан или общественных организаций, других институтов гражданского общества), установлена ответственность. В этом процессе существенно влияют на формирование указанной иерархии акты вспомогательного характера, которые также требуют определенного упорядочения и соответствия законам, то есть они должны разъяснять законы, толковать, а не дополнять или восполнять пробелы. Анализ проектируемого законодательства помогает отслеживать тенденции в украинском обществе, но пока не позволяет делать выводы о будущих принципах участия общественности в управлении государственными делами из-за постоянных изменений и непоследовательности в процессе работы над ним.

Ключевые слова: участие общественности, нормативно-правовое обеспечение, разъяснение, проект, решение суда, управление государственными делами.

The article is devoted to the review of auxiliary acts, which are an integral part of the system of legal and regulatory support for public participation in improving the efficiency of the functioning of executive bodies. It is determined that the problem of legal support for the studied participation is the lack of legal awareness in the country, even among officials, in particular, cases of management of officials of the executive power are not often covered by explanations, internal instructions in some cases - even contrary to the rules of the law, in other cases both the provisions of the law and the explanations thereto. This situation is also due to the fact that the process of public participa- 
tion in the management of public affairs is not clearly spelled out in a single piece of legislation, which would eliminate numerous contradictions and the need for additional clarification. It is concluded that the main purpose of the legal regulation of public participation in the management of public affairs should not be the ordering of civil society and its institutions, but the legal provision of the proper exercise of the right of citizens to the specified participation, the creation of a system of accessible, clear and clear hierarchy of normative and legal hierarchies. it should be consistent and accessible to determine the capabilities of citizens in the specified field, identify the entities that provide such security, establish forms of public participation in management of public affairs, defines the rights and duties of both public entities and the public (individual citizens or public organizations, other institutions of civil society), established responsibility. In this process, acts of ancillary character, which also require some ordering and, above all, compliance with the law, that is, they should clarify, interpret, and not fill or fill in the gaps, have a significant influence on the formation of the designated hierarchy. The analysis of the projected legislation makes it possible to follow trends in Ukrainian society, but does not yet allow conclusions to be drawn about the future principles of public participation in public affairs management due to constant changes and inconsistencies in the process of working on them.

Key words: public involvement, regulatory and legal framework, clarification, project, judicial decision, state affairs management.

Постановка проблеми та її актуальність. Питання нормативно-правового забезпечення участі громадськості в підвищенні ефективності функціонування органів виконавчої влади $\epsilon$ безсумнівно важливим, оскільки без такого забезпечення в принципі неможливе правове запровадження означеної участі. Вся нормативно-правова база участі громадськості в підвищенні ефективності функціонування органів виконавчої влади складається традиційно із законів, підзаконних нормативно-правових актів, актів допоміжного характеру й міжнародних актів.

Метою статті $\epsilon$ дослідження актів допоміжного характеру й перспективне законодавство. Останнє хоча й не $\epsilon$ елементом досліджуваної системи, все ж справляє вагомий вплив на подальший розвиток відносин в означеній сфері через те, що віддзеркалює наявні проблеми в нормативно-правовому забезпеченні участі громадськості в процесі, який ми вивчаємо.

Аналіз останніх досліджень і публікацій. У роботі використано наукові розробки М. Гирика, М. Габдуалі$€ в а$, В. Головка, П. Петренка, В. Мартиненка, А. Соколова, І. Скалабан, А. Халецького та інших учених, які тією чи іншою мірою розглядали питання участі громадськості в управлінні державними справами.

Виклад основного матеріалу. Перша група актів, які маємо на меті оглянути, це акти допоміжного характеру. В системі цих допоміжних актів щонайперше слід назвати роз'яснення Кабінету Міністрів, Центральних органів виконавчої влади (далі - ЦОВВ), які не створюють правових норм, проте $\epsilon$ важливими для побудови процесу участі громадськості в управлінні державними справами, оскільки мають скеровувальний вплив. Таким є, наприклад, Роз'яснення Міністерства юстиції України «Взаємодія держави та інститутів громадянського суспільства» від 3 лютого 2011 р. [1].

Пропонуємо звернути увагу також на Роз'яснення Міністерства фінансів України щодо можливості громадським об'єднанням займатися соціальним підпри- ємництвом [2], оскільки в такий спосіб створюються економічні можливості для розвитку громадських організацій і для того, щоб вони були менш залежні від донорів. Так, наприклад, у 2015 р. було внесено зміни до Податкового кодексу, згідно з якими громадські організації могли займатися підприємництвом. Державна фіскальна служба України (далі - ДФС) навіть дала роз'яснення з цього приводу, де зазначалося, що «громадська організація має право вести підприємницьку діяльність й отримувати дохід від неї, проте такий дохід не може бути розподілений між засновниками й членами громадської організації й має бути спрямований виключно на досягнення мети громадської організації» [3]. Отже, якщо непідприємницька організація $\epsilon$ громадським об'єднанням, утвореним з урахуванням вимог Закону № 4572, така організація може скористатися правом для отримання статусу неприбуткової організації відповідно до положень п. п. 133.1.1, 133.1 ст. 133 Податкового кодексу України за умови, що метою її діяльності не може бути одержання й розподіл прибутку серед засновників, членів органів управління, інших пов'язаних з ними осіб, а також серед працівників таких організацій». Однак з 2018 р. в окремих областях посадові особи ДФС стали відмовляти громадським організаціям в отриманні ознаки неприбутковості, якщо в їхніх статутах $\epsilon$ інформація про право займатись соціальним підприємництвом. В результаті було направлено запит до ДФС, яка відповіла, що вона не впевнена щодо можливості займатися підприємництвом громадським організаціям (благодійним організаціям це можна) і скерувала запит до Міністерства фінансів (далі - Мінфін). Активні громадські організації закликали громадськість залучитися до обговорення цієї проблеми з Мінфіном і ДФС. Як наслідок через пів року обговорень і дискусій у лютому 2019 р. було видано нове роз'яснення, яке поки що не має офіційних реквізитів, проте активно поширюється громадськими організаціями. На цьому прикладі бачимо одразу декілька нюансів правового забезпечення участі громадськості в управлінні державними справами.

По-перше, яскраво відображено непослідовність владної політики q непрофесійність посадових осіб ДФС, які на власний розсуд тлумачать норми Податкового кодексу, потім видають одне роз'яснення з приводу застосування цих норм, а згодом це ж роз'яснення не беруть до уваги й діють всупереч і нормам Податкового кодексу, і вже виданому ними ж роз'ясненню. По-друге, знайти означене роз'яснення можливо лише спеціалістам-юристам (у спеціальному виданні ДФС, тим більше без зазначення жодного реквізиту роз'яснення), але аж ніяк його оприлюднення не відповідає вимогам щодо доступу до публічної інформації. Це вказує на наявну проблему оприлюднення інформації органами державної влади. По-третє, непрофесійне знання юридичних основ податківцями, через що вони не можуть самостійно тлумачити норми Податкового кодексу, а керуються власними уявленнями, навіть ігноруючи роз'яснення ДФС, указує на необхідність посилення навчання працівників ДФС правових основ. По-четверте, позитивною $\epsilon$ активність громадських організацій, які не залишилися осторонь проблеми, що виникла, а почали їі активно розв'язувати, направляючи запити й запрошуючи всіх зацікавлених громадян до спільних дій, що можна характеризувати як здійсненну 
участь громадськості в поліпшенні функціонування органів виконавчої влади, адже насамкінець домоглися iї вирішення відповідно до тих засад, що притаманні правовим державам (зокрема, практика соціального підприємництва поширена в усіх розвинених країнах).

Проте, узагальнюючи викладене, маємо констатувати, що проблема з правовим забезпеченням функціонування громадських організацій, а отже i їхньої участі в управлінні державними справами, існує. I головне в ній те, що закон (у цьому випадку - Податковий кодекс) не виконується. Тобто право наштовхується на перешкоди в його реалізації, і це $\epsilon$ загальною проблемою всієї держави: невиконання законів. Цьому сприяє як мінімум два фактори, першим з яких $\epsilon$ неточність викладення законодавчих положень, що має бути усунута, адже закон повинен формулюватися таким чином, щоб не було подвійного його розуміння, оскільки «чіткість правової норми, що дістає прояв у детальній визначеності, $є$ не тільки правовою гарантією захисту основоположних прав і свобод людини від свавільного втручання з боку держави, а й засобом, що обмежує дискреційні повноваження органів державної влади» [4, с. 215]. І.І. Оніщук правильно зазначає, що «порушення правил юридичної техніки в тексті нормативно-правових актів істотно знижує їх якість, викликає неоднозначність їх тлумачення й перешкоджає реалізації норм права в конкретних відносинах» [5, с. 30]. Другий фактор - відсутність відповідальності посадових осіб державних органів за неякісне надання державних послуг, тобто за виконання свої прямих повноважень. Так, у наведеному прикладі з приводу соціального підприємництва чи понесли хоч яку-небудь відповідальність працівники ДФС, які відмовили громадським організаціям в їх реєстрації як неприбуткових? Чи було хоч яким-небудь чином відшкодовано цим громадським організаціям збитки, які вони ймовірно понесли, змінюючи формулювання статуту й виключаючи з нього положення про соціальне підприємництво та навпаки - знову маючи необхідність вносити це положення після підтвердження цього права роз'ясненням ДФС? Очевидно, що ці питання навіть не постають сьогодні в українській системі побудови громадянського суспільства.

Друга група актів допоміжного характеру - це судові рішення. М. Гирик справедливо зазначає, що «ієрархічна система нормативно-правових актів має динамічний характер і тяжіє до свого постійного удосконалення. По-перше, ця система розширюється шляхом поповнення від нових джерел права, зокрема рішень Конституційного Суду України й судів загальної юрисдикції. По-друге, відбувається удосконалення системи чинного законодавства про участь громадськості в державному управлінні» [6, с. 199]. Слід погодитися, що означені акти мають допоміжний характер у правовому регулюванні участі громадськості.

Справ такої категорії (відмова від проведення легалізації через хибне встановлення організаційно-правової форми громадського об'єднання (далі ГО); відмова від реєстрації через складнощі з визначенням територіальності ГО у зв'язку з зазначенням двох областей як території дії; відмова від реєстрації змін до установчих документів тощо) достатньо багато (зокрема справи №№ 2a-894/12/1370, 2a-2893/12/2670, 2a/0370/961/12, 2312/698/201 та інші), тому рішення судів загальної юрисдикції дійсно поповнюють джерельну базу регу- лювання діяльності ГО і сприяють певною мірою удосконаленню такому регулюванню шляхом висвітлення проблем у наявному правовому регулюванні. Прикладом $є$ також постанова Верховного суду України (далі ВС) від 3 травня 2018 р. у справі № 804/5750/17, якою було принципово вирішено питання про можливість громадських об'єднань без статусу юридичної особи звертатися до суду по захист своїх прав; водночас було роз'яснено, що такі громадські організації звільняються від сплати судового збору.

Окрім зазначеного, допоміжними джерелами нормативно-правової бази участі громадськості можна назвати також і документи роз'яснювального характеру, як, наприклад, викладена Вищим адміністративним судом України (далі - ВАСУ) Довідка щодо вивчення та узагальнення практики застосування адміністративними судами положень Закону України «Про громадські об'єднання» від 22 березня 2012 р. № 4572 [7].

Окрему увагу приділимо проєктованому законодавству. Зауважимо, що суттєвого значення для вдосконалення правового забезпечення участі громадськості в управлінні державними справами набуває перспективне законодавство. Йдеться насамперед про проєкт закону «Про громадський контроль», який досі не прийнято. Так, у 2014 р. на розгляд ВР України було внесено проєкт відповідного закону від С.Л. Тігіпка, проте подальшого руху ця редакція проєкту не отримала, що в принципі зрозуміло, оскільки навіть поверховий аналіз свідчить про недостатню правову якість цього закону. у 2015 р. від Н.Ю. Королевської та Ю.В. Солода було подано інший проєкт з аналогічною назвою, який був на розгляді понад півтора року, декілька разів доопрацьовувався, але наприкінці 2016 р. був знятий з розгляду, хоча містив більш прогресивні положення, ніж проєкт С.Л. Тігіпка. У 2018 р. зареєстровано новий законопроєкт «Про громадянський контроль за діяльністю органів влади, їх посадових і службових осіб» (С.М. Каплін). Якщо навіть не вдаватися до причин заміни понять «громадський контроль» «громадянським контролем» (яка до речі не пояснюється в пояснювальній записці до законопроєкту), то слід вказати на принципово інший підхід до участі громадськості в управлінні державними справами, закладений в цьому законопроєкті. Попри те, що законопроєкт містить новації, вводячи такі форми громадянського контролю, як пікетування адміністративних будинків, ініціювання й проведення громадського публічного розслідування в разі виявлення фактів порушення вимог актів законодавства, здійснення контролю за оперативністю реагування на відповідну інформацію й повідомлення, все ж він має агресивний характер, навіть офіційно пропонуючи ввести поняття «громадянського спротиву» й по суті він не спрямований на побудову цілісної системи громадського контролю на різних етапах функціонування органів державної влади, а $є$ фрагментарним, який переслідує основною метою закріплення можливості громадян (а так само й іноземних громадян) тільки через громадські об'єднання й інші форми громадянського суспільства (а не самостійно) висловлення своєї незгоди з діями уповноважених органів державної влади. Вважаємо, що такий зміст законопроєкту не зовсім відповідає суті побудови громадянського суспільства, яка, навпаки, спрямована на мирне розв'язання конфліктів, на взаємодію. Проте ідея, закладена в проєкті, заслуговує на увагу, зокрема 
в частині, що стосується надання визначених в проєкті можливостей для громадян здійснювати реальний вплив на діяльність органів влади. Однак не можна в жодному разі підтримати окремі положення законопроєкту, закладені, наприклад, у ч. 5 ст. 7 проєкту, а саме: «Ненадання, несвоєчасне надання або надання не в повному обсязі посадовими й службовими особами органів влади відповіді на письмові звернення суб'єктів громадянського контролю вважається корупційним правопорушенням». Такий підхід суперечить взагалі поняттю корупційного правопорушення, його ознакам і змісту. Водночас пропозиція про встановлення персональної відповідальності колегіальних органів державної влади за прийняття такими органами рішень, що призвели до порушення вимог актів законодавства (в тому числі за результати їх особистого голосування), або якщо такі особи відповідно до своїх повноважень не відреагували або своєчасно не відреагували на заходи громадянського контролю, могла б вирішити вище зазначену проблему, яку ми описували щодо надання можливості громадським організаціям займатися соціальним підприємництвом. Отже, на нашу думку, можна стверджувати, що проєкт потребує суттєвого доопрацювання, а точніше потрібен новий закон про громадський контроль, в якому окремими положеннями може бути закріплено низку положень, висунутих у цьому проєкті.

Ще одним важливим законопроєктом, який уже давно чекає на прийняття, $є$ Адміністративно-процедурний кодекс. Науковці очікують від нього виправлення ситуації, яка склалася наразі в Україні. Зокрема «Необґрунтовані відмінності нормативно-правових актів, що містять адміністративно-процедурні норми для різних сфер та органів публічного адміністрування, а також для окремих адміністративно-територіальних одиниць об'єктивно призводять до прогалин у правовому регулюванні. В кінцевому підсумку недостатній рівень правових приписів i, відповідно, незрозумілість багатьох адміністративних процедур для громадян і суб'єктів господарювання зумовлює зниження рівня довіри громадськості до публічної влади. <...> Тому істотна модернізація адміністративно-процедурного законодавства, включаючи ухвалення загального закону (кодексу) про адміністративну процедуру $\epsilon$ просто необхідною для належного функціонування правової системи й державно-правових інститутів в Україні» [8, с. 37]. Робота над кодексом триває.

Висновки. Підсумовуючи все вище викладене, відзначимо, що важливою проблемою правового забезпечення досліджуваної участі $\epsilon$ відсутність у країні правової обізнаності навіть серед посадових осіб, зокрема непоодинокими є випадки, коли посадові особи органів виконавчої влади керуються (навіть усупереч нормам закону) роз'ясненнями, внутрішніми інструкціями в одних випадках, а в інших випадках ігнорують як нормами закону, так і роз'ясненнями до них. Така ситуація обумовлена в тому числі й тим, що процес участі громадськості в управлінні державними справами не прописаний чітко в єдиному законодавчому акті, яким би усувалися численні суперечності й необхідність в додаткових роз'ясненнях. Правильною вважаємо пропозицію В.В. Головка щодо необхідності розробки Закону України «Про участь громадськості в управлінні державними справами» [9, с. 25], в якому було б уніфіковано основні процеси означеної участі.
По-друге, важливо підкреслити справедливість зауваження М. Гирика щодо правового забезпечення участі громадськості в управлінні державними справами: «Держава повинна забезпечувати ефективні юридичні механізми взаємодії громадянських інститутів 3 державою та її органами, а також захист законних прав і інтересів членів громадянського суспільства». Натомість держава повинна відмовитися від намірів «упорядкувати» чи «структурувати» громадянське суспільство. На обґрунтування цієї тези вчений наводить висловлювання А. фон Хаєка: «Збереження стихійного порядку суспільства $\epsilon$ головною умовою суспільного блага його членів, у чому й полягає значення правил суспільної поведінки». Тобто громадянське суспільство представлене передусім системою своїх саморегульованих інститутів, виникнення, модернізація чи занепад яких обумовлюється самими потребами громадянського суспільства й змістом легітимних механізмів його взаємодії з державою» [10, с. 194-195]. Тобто основною метою правового регулювання участі громадськості в управлінні державними справами має бути не упорядкування громадянського суспільства та його інституцій, а правове забезпечення належної реалізації права громадян на означену участь, створення системи доступної, зрозумілої й чіткої ієрархії нормативно-правових актів, в яких має бути послідовно й доступно визначено можливості громадян у вказаній сфері, визначено суб'єктів, які здійснюють означене забезпечення, встановлено форми участі громадськості в управлінні державними справами, визначено права й обов'язки як державних суб'єктів, так і громадськості (окремих громадян чи громадських організацій, інших інститутів громадянського суспільства), встановлено відповідальність. Звісно, що в цьому процесі вагомий вплив на формування означеної ієрархії чинять акти допоміжного характеру, які також потребують певного упорядкування й насамперед відповідності законам, тобто вони мають його роз'яснювати, тлумачити, а не доповняти чи заповнювати прогалини. Аналіз проєктованого законодавства допомагає відстежувати тенденції в українському суспільстві, але поки що не дає змоги робити висновки про майбутні засади участі громадськості в управлінні державними справами через постійні зміни й непослідовність у процесі роботи над ним.

\section{Література}

1. Взаємодія держави та інститутів громадянського суспільства : Роз'яснення Мін'юсту України від 03 лютого 2011 р. База даних «Законодавство України». URL: https: / /zakon.rada.gov.ua/laws/show/n0018323-11.

2. Повідомлення ДФС стосовно можливості здійснення громадськими об'єднаннями підприємницької діяльності і включення таких об'єднань до Реєстру неприбуткових установ та організацій URL: https://drive.google.com/file/ d/1TZAytBCMq-22vEd6JeyCOytRSX9wkQxZ/view.

3. Щодо здійснення неприбутковою організацією підприємницької діяльності : Роз'яснення ДФС. Офіційне видання ДФС України. URL: http://www.visnuk.com.ua/ ua/pubs/id/8724.

4. Загальна теорія права : підручник / За заг. ред. м.І. Козюбри. Київ : Ваіте, 2015. 392 с.

5. Онищук I.І. Принципи, методи та етапи здійснення моніторингової експертизи нормативно-правових актів / I.І. Онищук. Наше право. № 8, 2014. С. 25-31.

6. Гирик М. Механізми участі громадськості в державному управлінні: правові аспекти. Збірник наукових 
праць Національної академії державного управління при Президентові України. 2010. Вип. 2. С. 191-202. URL: http://nbuv.gov.ua/UJRN/znpnadu_2010_2_20.

7. Довідка ВАСУ щодо вивчення та узагальнення практики застосування адміністративними судами положень Закону України від 22 березня 2012 р. № 4572-VI «Про громадські об'єднання». URL: http://www.vasu.gov. ua/sudovapraktika/uzagalnennya/uzagalnenna_gromadski_ objednanna/.

8. Школик А.М. Адміністративно-процедурне право: ідея та реалізація. LEX PORTUS. № 5 (7). 2017. C. 30-40.

9. Головко В.В. Адміністративно-правове забезпечення реалізації громадянами України права на участь в управлінні державними справами : дис. ... канд. юрид. наук :
12.00.07. Київський. нац. ун-т ім. Тараса Шевченка. Київ, 2018. 269 с.

10. Гирик М. Оптимізація механізмів участі громадськості в державному управлінні на сучасному етапі державотворення. Вісник Національної академії державного управління при Президентові України. 2010. № 3. C. 190-199. URL: http://nbuv.gov.ua/UJRN/ Vnadu_2010_3_28.

Юрах B. M., кандидат юридичних наук, Донецький юридичний інститут Міністерства внутрішніх справ України 